\title{
Oceanography
}

CITATION

Rabalais, N.N., W.-J. Cai, J. Carstensen, D.J. Conley, B. Fry, X. Hu, Z. Quiñones-Rivera,

R. Rosenberg, C.P. Slomp, R.E. Turner, M. Voss, B. Wissel, and J. Zhang. 2014.

Eutrophication-driven deoxygenation in the coastal ocean. Oceanography 27(1):172-183,

http://dx.doi.org/10.5670/oceanog.2014.21.

DOI

http://dx.doi.org/10.5670/oceanog.2014.21

COPYRIGHT

This article has been published in Oceanography, Volume 27, Number 1, a quarterly journal of The Oceanography Society. Copyright 2014 by The Oceanography Society. All rights reserved.

USAGE

Permission is granted to copy this article for use in teaching and research. Republication, systematic reproduction, or collective redistribution of any portion of this article by photocopy machine, reposting, or other means is permitted only with the approval of The Oceanography Society. Send all correspondence to: info@tos.org or The Oceanography Society, PO Box 1931, Rockville, MD 20849-1931, USA. 
SPECIAL ISSUE ON CHANGING OCEAN CHEMISTRY » ANTHROPOCENE: THE FUTURE...SO FAR

\section{Eutrophication-Driven Deoxygenation in the Coastal Ocean}

BY NANCY N. RABALAIS, WEI-JUN CAI, JACOB CARSTENSEN, DANIEL J. CONLEY, BRIAN FRY, XINPING HU, ZORAIDA QUIÑONES-RIVERA, RUTGER ROSENBERG, CAROLINE P. SLOMP, R. EUGENE TURNER, MAREN VOSS, BJÖRN WISSEL, AND JING ZHANG

ABSTRACT. Human activities, especially increased nutrient loads that set in motion a cascading chain of events related to eutrophication, accelerate development of hypoxia (lower oxygen concentration) in many areas of the world's coastal ocean. Climate changes and extreme weather events may modify hypoxia. Organismal and fisheries effects are at the heart of the coastal hypoxia issue, but more subtle regime shifts and trophic interactions are also cause for concern. The chemical milieu associated with declining dissolved oxygen concentrations affects the biogeochemical cycling of oxygen, carbon, nitrogen, phosphorus, silica, trace metals, and sulfide as observed in water column processes, shifts in sediment biogeochemistry, and increases in carbon, nitrogen, and sulfur, as well as shifts in their stable isotopes, in recently accumulated sediments.

Photos from top to bottom: (1) Diopatra cuprea polychate burrow (middle right) amid Beggiatoa bacterial mat and organic detritus. Photo credit: Franklin Viola. (2) Fish kill on Grand Isle beach, Louisiana, as a result of anoxic waters impinging on shoreface. Photo credit: Kerry M. St. Pé. (3) Mississippi River sediment and dissolved nutrient-laden plume from Southwest Pass entering the oligotrophic waters of the open Gulf of Mexico. Photo credit: Nancy Rabalais. (4) Dead spider crab from Gulf of Mexico hypoxic zone. Photo credit: Franklin Viola. (5) Dead polychaete worm amid Beggiatoa bacterial mat and black anoxic sediments. Photo credit: Franklin Viola. 


\section{INTRODUCTION}

Deoxygenation has become a focus of open ocean research in the last 10 years (Keeling et al., 2010). However, lowoxygen areas, sometimes called "dead zones," have been known for much longer in the coastal ocean and have increased in size and number during the last several decades (Díaz and Rosenberg, 2008). Gilbert et al. (2010) concluded that the median oxygen decline rates observed in extensive data sets are more severe in a $30 \mathrm{~km}$ band near the coast than in the open ocean (> $100 \mathrm{~km}$ from the coast). Also, oxygen time series with negative oxygen trends are more prevalent in the coastal ocean than in the open ocean.

There have always been some hypoxic (low dissolved oxygen) and anoxic (no oxygen) aquatic environments. Lowoxygen waters in the world ocean are normal, or naturally formed, in areas such as oxygen minimum zones (OMZs), high productivity areas such as upwelling regions, and restricted basins and fjords (Helly and Levin, 2004; Rabalais et al., 2010). Human activities in the nineteenth, twentieth, and twenty-first centuries have resulted in many more areas of hypoxia than have occurred historically, and they have aggravated conditions in areas that were already low in oxygen (Figure 1; Díaz and Rosenberg, 2008). The exponential growth rate of coastal sites where hypoxia has been reported is $5.5 \% \pm 0.23 \% \mathrm{yr}^{-1}\left(\mathrm{R}^{2}=0.86\right.$, $\mathrm{P} \leq 0.01$ ) (Vaquer-Sunyer and Duarte, 2008). A close examination of waterquality data (e.g., coastal areas of the Baltic Sea) reveals additional areas of low oxygen not formally documented in the scientific literature (Figure 2).

These changes in oxygen are increasingly important because of their large impacts on ecosystems and their biogeochemical cycles. And, unlike the open ocean, deoxygenation at the shallow coastal margins results in changes to sediment chemistry that accompany the shifts in biogeochemistry observed in the overlying water.

Some of the reasons that hypoxia is a focus of scientific research and applied science are that it may have undesirable effects on ecosystems, including loss of suitable and required habitat for many bottom-dwelling fishes and benthic fauna; habitat compression for pelagic fishes; direct mortality; increased predation; decreased food resources; and altered trophic energy transfer, bioenergetics (physiological, development, growth, and reproductive abnormalities), and migration (Rabalais et al., 2001). The increased nutrient loads causing hypoxia may also change the composition of the phytoplankton community and can shift trophic interactions (Turner et al., 1998). Hypoxia also alters or interrupts ecosystem functions, such as nutrient cycling and bioturbation (Rabalais, 2004; Middelburg and Levin, 2009).

\section{DEFINITIONS}

Deoxygenation in the coastal ocean often results in hypoxia or even anoxia, which are detrimental to aerobic, aquatic organisms. The behavioral and physiological responses may include reduced growth, loss of reproductive capacity, mortality, reduced biodiversity, and loss of secondary production, including fisheries. But, there is no simply defined oxygen concentration at which marine, coastal, or estuarine waters become hypoxic to the resident organisms, nor is there consistency in the units of oxygen used to define hypoxia. Dissolved oxygen concentration varies depending on temperature (low temperature increases $\mathrm{O}_{2}$ solubility), pressure (high pressure increases $\mathrm{O}_{2}$ solubility), and salinity (higher salinity decreases $\mathrm{O}_{2}$ solubility). Shrimp and fish, for example, avoid dissolved oxygen levels below $2 \mathrm{mg} \mathrm{L}^{-1}(63 \mu \mathrm{M})$ in the northern Gulf of Mexico hypoxic zone, while sharks and rays emigrate from the area at a dissolved oxygen concentration of $3 \mathrm{mg} \mathrm{L}^{-1}$ (94 $\mu \mathrm{M}$; Rabalais et al., 2001). There is,

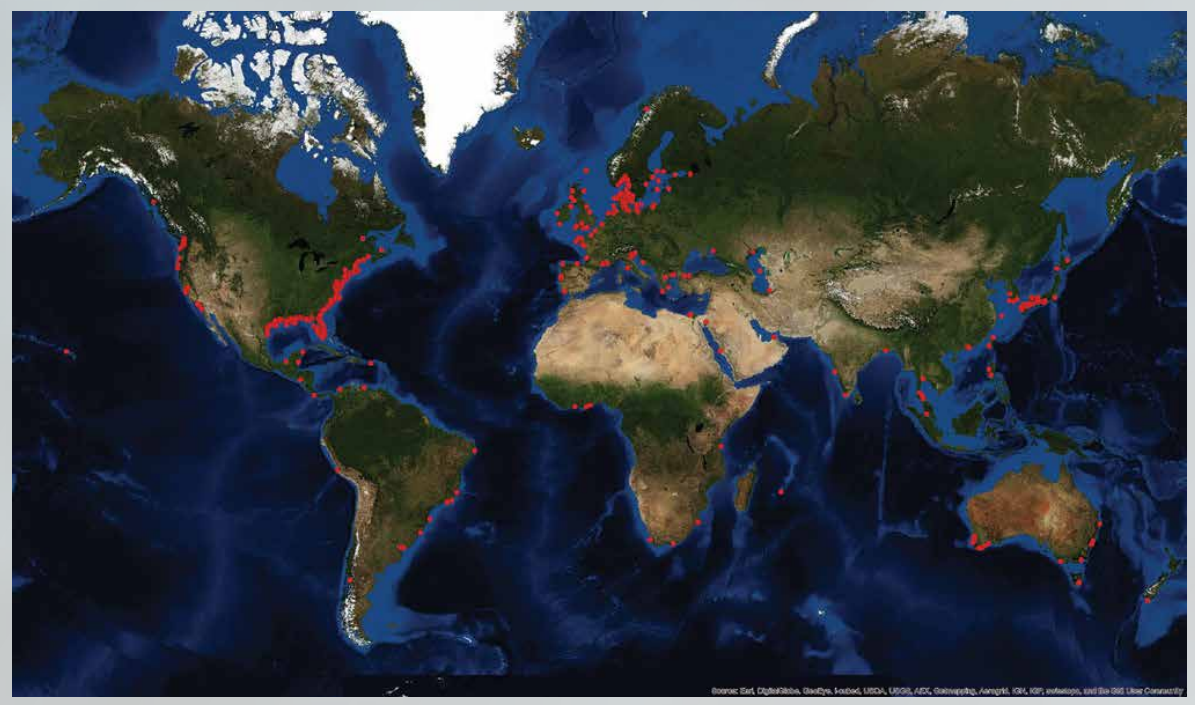

Figure 1. Global coastal hypoxia. Each red $\operatorname{dot}(n=480)$ represents a documented case related to human activities. The data were compiled using a literature search conducted by Robert Díaz, Virginia Institute of Marine Science; Rutger Rosenberg, Gothenburg University; and the Water Resources Institute. Data replotted from http://www.wri.org/our-work/project/eutrophication-and-hypoxia/ interactive-map-eutrophication-hypoxia 
in fact, a broad range in the oxygen sensitivity of marine organisms that complicates the definition of a common stress threshold (Vaquer-Sunyer and Duarte, 2008). Nevertheless, the Scientific Committee on Oceanic Research, Working Group 128, agreed to consider a general value for hypoxia of 30\% oxygen saturation at $25^{\circ} \mathrm{C}$ and salinity 35 (= $2 \mathrm{mg} \mathrm{L}^{-1}, 1.4 \mathrm{ml} \mathrm{L}{ }^{-1}, 63 \mu \mathrm{M}$; Rabalais et al., 2010). This value is most relevant as a threshold to coastal waters and organisms that have evolved in normoxic (oxygenated) waters without severe hypoxia. Hofmann et al. (2011), however, make the case for use of $\mathrm{pO}_{2}$, in units of milli-atmospheres (matm), as the standard unit for oxygen thresholds to facilitate a combination of $\mathrm{pO}_{2}$ fields and $p \mathrm{CO}_{2}$ fields (generally reported in $\mu$ atm units) when considering the effects of ocean acidification and climate change.

The term "dead zone" most often applies to near-bottom coastal waters

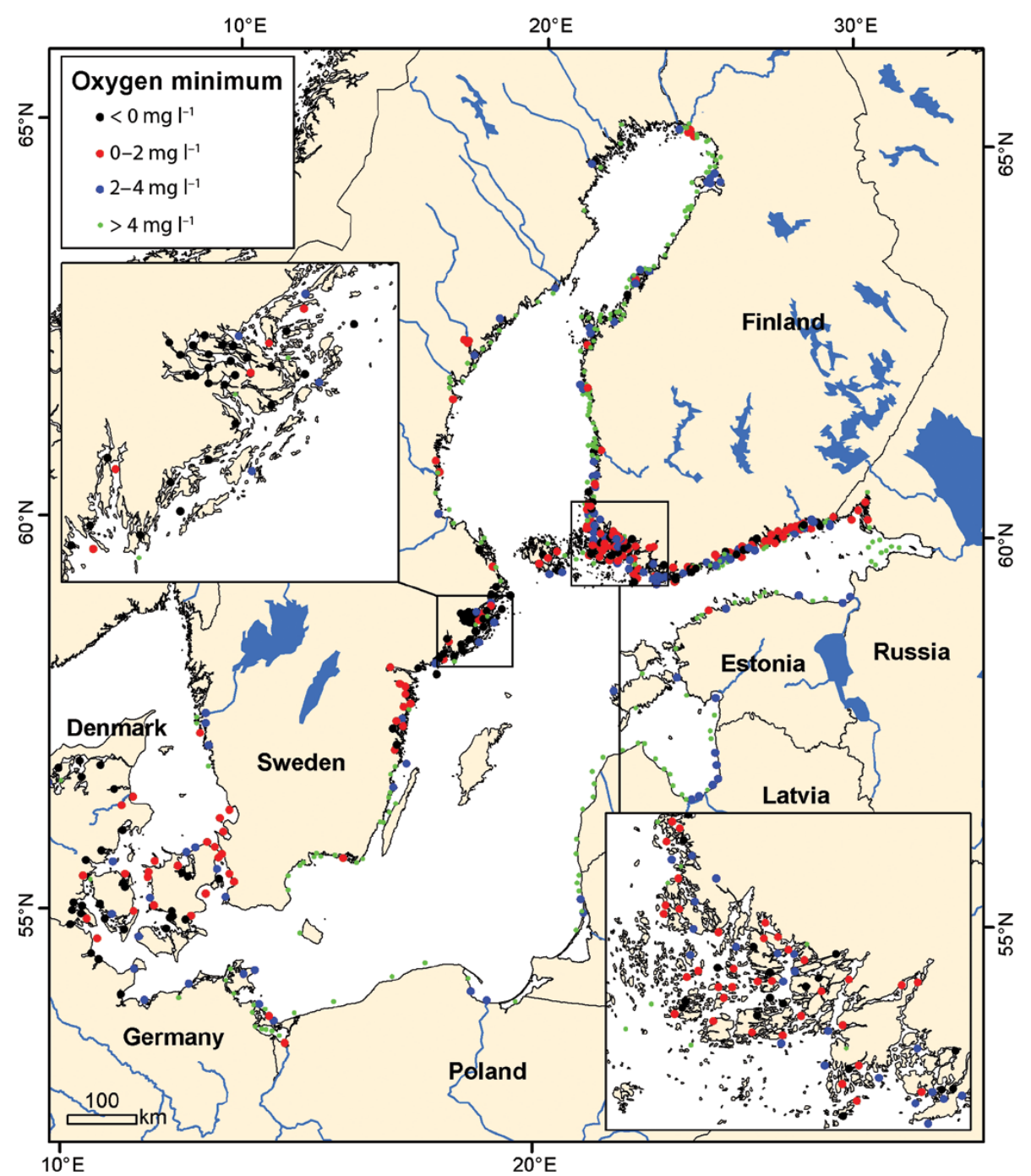

Figure 2. Lowest recorded oxygen concentration at all monitoring locations from 1955 to 2009 in the entire Baltic Sea. The insets are the Stockholm Archipelago (upper left) and the Finnish Archipelago Sea (lower right). Oxygen concentrations in bottom waters are divided into four categories: $<0 \mathrm{mg} \mathrm{L}^{-1}, 0$ to $2 \mathrm{mg} \mathrm{L}^{-1}(0$ to $63 \mu \mathrm{M}), 2$ to $4 \mathrm{mg} \mathrm{L}^{-1}$ (63 to $\left.125 \mu \mathrm{M}\right)$, and $>4 \mathrm{mg} \mathrm{L}^{-1}$ (> $125 \mu \mathrm{M}$ ). Oxygen concentrations of $0 \mathrm{mg} \mathrm{L}^{-1}$ are considered anoxic, 0 to $2 \mathrm{mg} \mathrm{L}^{-1}(0$ to $63 \mu \mathrm{M})$ are considered hypoxic, and 2 to $4 \mathrm{mg} \mathrm{L}^{-1}(63$ to $125 \mu \mathrm{M})$ are considered oxygen stressed. Reprinted with permission from Conley et al. (2011), @ 2011 American Chemical Society

where oxygen depletion occurs in otherwise normoxic waters, with migration or mortality of charismatic megafauna (i.e., fishes and large invertebrates). The regions are not, of course, truly "dead." Even in the absence of larger fauna, smaller meiofaunal taxa (foraminiferans, nematodes) and microbes persist, and the upper water column is fully oxygenated and supports diverse metazoan communities, including fisheries. The term "dead zone" is probably not appropriate for shelf and slope regions with permanent oxygen depletion (oxygen minimum zones or oxygen minimum layers), where fully developed, diverse animal communities with megafauna can occur at $\mathrm{O}_{2}$ concentrations below $2 \mathrm{mg} \mathrm{L}^{-1}$ (63 $\mu \mathrm{M}$; Levin, 2003).

\section{HYPOXIC ZONES IN}

\section{COASTAL WATERS}

There were scattered reports of hypoxia in North America and northern Europe before 1970. By the 1990s, coastal hypoxia was prevalent in North America, northern Europe, and Japan. By the 2000s, there were increased reports of hypoxia in South America, southern Europe, and Australia (Figure 1). These coastal hypoxic systems include estuaries and continental shelf waters that extend from the barrier island shoreface to the edge of the continental shelf at $100 \mathrm{~m}$ water depth. Often, phytoplankton production in shallower waters is not likely to be high, despite high nutrient delivery, because of turbidity caused by sediment resuspension or sediment delivery from coastal rivers (Rabalais et al., 2007a). Also, deeper waters at the edge of the continental shelf are not as conducive to eutrophication-induced hypoxia because nutrients are depleted with distance offshore, less primary production occurs there, and less organic matter is exported 
from surface waters. Further, stratification is less likely in shallow waters due to mixing events. Stratification is a key requirement in the formation of hypoxia or anoxia (Rabalais et al., 2007a). During most or part of the year, salinity or temperature or both change dramatically from the surface to the seabed. The physical differences in the resulting density prevent oxygen from diffusing from surface waters toward the lower water column. Swift currents that move materials away from the river discharge and that do not permit the development of stratification are not conducive to the accumulation of biomass or depletion of oxygen, for example, in the Amazon and Orinoco plumes. Similar ocean circulation processes off the Changjiang (Yantze) River were once thought to be reasons why hypoxia did not develop in the coastal waters of the East China Sea. Yet recently, a significant area of hypoxia has been documented off the Changjiang in summer (Chen et al., 2007). There is increasing likelihood that, where physical conditions are conducive, more and more coastal systems will become eutrophic, especially in developing countries (Figure 3).

Many currently hypoxic systems were not always hypoxic. The declines in oxygen concentrations for systems with data from the first half of the twentieth century started, for example, in the 1950s and 1960s for the northern Adriatic Sea (Justić et al., 1987), between the 1940s and 1960s for the northwest continental shelf of the Black Sea (Zaitsev, 1992), and in the 1970s for the Kattegat (Baden et al., 1990). Declining dissolved oxygen levels were noted in the Baltic Sea as early as the 1930s (Fonselius, 1969), but it wasn't until the 1950s that hypoxia became widespread (Karlson et al., 2002). Other systems have been hypoxic since the beginning of oxygen data collection-in the 1930s for the Chesapeake Bay (Cooper and Brush, 1991; Brush, 2009) and the 1970s for the northern Gulf of Mexico (Rabalais et al., 2002).

\section{CAUSES AND EFFECTS}

Eutrophication (an increase in the rate of primary production and carbon accumulation) usually causes decreasing dissolved oxygen in coastal waters, which leads to microbial oxygen consumption in the lower portion of a stratified water column that exceeds the re-aeration rate (Rabalais, 2004). (This does not apply to upwelling-driven systems or oxygen minimum zones.) The development and global distribution of coastal hypoxia areas is closely associated with developed watersheds, the coupling between increased nutrient loads, especially nitrogen and phosphorus, and higher carbon

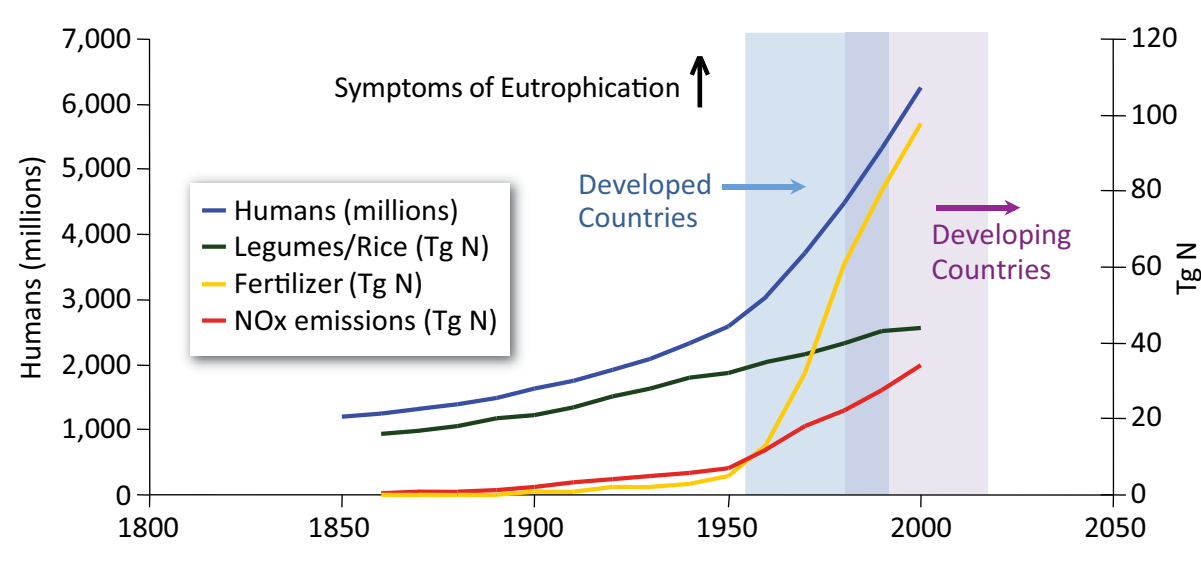

Figure 3. Period in which the symptoms of eutrophication and hypoxia/anoxia began in developed countries and the more recent evolution of these symptoms in developing countries (Rabalais et al., 2010). Used under Copyright Agreement with Copernicus Press.

Nancy N. Rabalais (nrabalais@lumcon.edu) is Executive Director and Professor, Louisiana Universities Marine Consortium, Chauvin, LA, USA. Wei-Jun Cai is Professor, College of Earth, Ocean, \& Environment, University of Delaware, Newark, DE, USA. Jacob Carstensen is Professor, Department of Bioscience, Aarhus University, Roskilde, Denmark.

Daniel J. Conley is Professor, Department of Geology, Lund University, Lund, Sweden. Brian Fry is Professor, Australian Rivers Institute, Griffith University, Nathan, Queensland, Australia. Xinping Hu is Assistant Professor, Department of Physical \& Environmental Sciences, Texas A\&M University, Corpus Christi, TX, USA. Zoraida Quiñones-Rivera is Research Scientist, Department of Biology, University of Regina, Regina, Canada. Rutger Rosenberg is Professor Emeritus, Department of Biological and Environmental Sciences, Gothenburg University, Fiskebäckskil, Sweden. Caroline P. Slomp is Professor of Marine Biochemistry, Department of Earth Sciences, Utrecht University, Utrecht, the Netherlands. R. Eugene Turner is Professor, School of the Coast \& Environment, Louisiana State University, Baton Rouge, LA, USA. Maren Voss is a researcher at the Leibniz-Institute for Baltic Sea Research, Rostock, Germany. Björn Wissel is Associate Director, Institute of Environmental Change and Society, University of Regina, Regina, Canada. Jing Zhang is Professor, State Key Laboratory of Estuarine and Coastal Research, East China Normal University, Shanghai, China. 
production. The size of the hypoxic zone adjacent to the Mississippi River, for example, is closely related to the nitrate load of the river for the two months before the mapping, and the same-sized hypoxic area is now formed with a lower nitrate load than historically (Turner et al., 2012; similarly, in Chesapeake Bay [Hagy et al., 2004]). The industrial creation of reactive nitrogen, which has increased by over 20 times since the Industrial Revolution to a global production of $187 \mathrm{Tg} \mathrm{N} \mathrm{yr}^{-1}$ in 2005 , drives the changes in nitrogen loading in the last 100 years (Galloway et al., 2008). Also, the increased flux of phosphorus from land runoff and wastewater effluents has elevated the global flux of phosphorus to the ocean almost threefold to current loadings of $\sim 22 \mathrm{Tg} \mathrm{yr}^{-1}$ (Bennett et al., 2001). The dissolved silicon concentration or loads (or both), however, have remained the same or decreased, so that the relative proportions of silicon to nitrogen and silicon to phosphorus in river effluents have decreased over time (Justić et al., 1995). The result of these changes is that phytoplankton biomass increases where nitrogen or phosphorus or both are limiting (Turner and Rabalais, 2013), and diatom growth may be limited or there may be shifts in diatom composition where the relative proportion of silicate to nitrogen approaches the Redfield ratio of 1:1 (Turner et al., 1998). The overall result is higher primary production, greater flux of organic carbon to the bottom later, and more extensive bottom-water hypoxia where the necessary physical structure exists (i.e., prolonged stratification; Turner and Rabalais, 1994; Parsons et al., 2002).

On a global level, the various physical processes, such as coastal upwelling and slope water intrusion, bring more dissolved inorganic nitrogen and phosphorus fluxes to continental margins than rivers, perhaps by a factor of six to nine for nitrogen and by two to three for phosphorus (Liu et al., 2010). However, a significant fraction of marine originated nitrate may be transported back to the ocean unused (Pomeroy et al., 2000), resulting in an almost balanced $\mathrm{N}$ budget for the coastal ocean (Voss et al., 2013). How much and how long the newly created hypoxic zones last depends on the residence time of riversupplied freshwater, nutrient uptake and regeneration rates, and other changes observed in the Anthropocene (or yet to come) because of climate-driven changes in oceanic nutrient sources.

\section{ALTERED CHEMISTRY OF WATER AND SEDIMENTS}

Oxygen dynamics are closely integrated with the chemistry of carbon, nitrogen, phosphorus, silica, trace metals, and sulfide in the water column and sediments. The chemical milieu associated with declining dissolved oxygen concentrations depends on the length of exposure to decreased oxygen content or the degree of severity (in concentration). The severity becomes more important to shifts in redox chemistry at oxygen concentrations less than $0.5 \mathrm{mg} \mathrm{L}^{-1}$ and at $0.05 \mathrm{mg} \mathrm{L}^{-1}(16 \mu \mathrm{M}$ and $1.6 \mu \mathrm{M})$ when hydrogen sulfide is released from the sediments into the overlying water (Rabalais et al., 2007a).

Highly productive surface waters often result in oxygen saturation levels greater than $100 \%$ on a seasonal basis (Quiñones-Riviera et al., 2010). Oxygen supersaturated waters are accompanied by lower $p \mathrm{CO}_{2}$ and higher $\mathrm{pH}$ values (Guo et al., 2012). However, due to rapid gas exchange with the atmosphere, the "excess" $\mathrm{O}_{2}$ in surface waters can be lost to the atmosphere before being mixed down into the water column. In bottom or subsurface waters, the amount of $\mathrm{O}_{2}$ consumed by organic matter exported from the surface and accumulated in subsurface/bottom waters cannot be easily resupplied due to the physical stratification.

Deoxygenation does not affect the dissolved and particulate organic carbon (DOC and POC, respectively) sources in surface waters and sediments, but they are the ultimate cause of decreasing oxygen concentrations. The question of how much carbon is imported from terrestrial sources versus how much carbon derives from in situ nutrient-enhanced production, which serves as the substrate for aerobic decomposition, is often debated with regard to causes and ultimate mitigation. For example, stable carbon isotopic $\left(\delta^{13} \mathrm{C}\right)$ compositions of DOC and POC indicate that terrestrially derived carbon from the Mississippi River basin is more ${ }^{13} \mathrm{C}$-depleted than carbon fixed in offshore waters, and that marine in situ production dominates (Wang et al., 2004; Figure 4). In addition, the $\delta^{13} \mathrm{C}$ composition of surface sediments indicates that the terrestrial carbon flux is located near the river mouth and adjacent to the wetlands. Instead, an in situ source of carbon, not a terrestrial source, dominates the Mississippi delta region where hypoxia develops (Turner and Rabalais, 1994). A potential carbon or nitrogen source from eroding wetlands appears to be relatively small compared to the river-derived carbon or nitrogen loading spread out over the same continental shelf (Turner et al., 2007; Figure 4).

"Unused" organic material in the form of senescent phytoplankton, fecal pellets, and marine aggregates sinks to the lower water column and the seabed where the organic carbon is 
remineralized by aerobic and anaerobic processes, or it is buried. As aerobic bacteria decompose the organic matter that falls into the lower water column or settles onto the seabed, the dissolved oxygen concentration in water overlying the sediments declines and bottom waters may become hypoxic or approach anoxia. In this transition, numerous biological and geochemical shifts occur in the benthic community, many with feedbacks that contribute to further eutrophication and declining oxygen levels (Middelburg and Levin, 2010).

Quiñones-Rivera et al. (2007) estimated the relative contributions of water column and benthic respiration in the hypoxic part of the northern Gulf of Mexico from oxygen concentrations and stable oxygen isotope measurements. Their model indicated that the severe bottom water oxygen depletion in midsummer 2001 was due predominantly to benthic respiration (73\%). Despite considerable overlap in oxygen saturation values, the relative contributions of benthic respiration in bottom waters during the summer season (75\%) were noticeably higher and more variable compared to the winter season (42\%) (QuiñonesRivera et al., 2010). There is also midwater respiration, where sinking organic matter accumulates at the pycnocline.

Eutrophication generally leads to reduced surface water $p \mathrm{CO}_{2}$ in the coastal region because of enhanced surface primary production. This $p \mathrm{CO}_{2}$ reduction is especially conspicuous in estuaries of nutrient-laden large rivers such as the Mississippi (Cai, 2003). Meanwhile, the $\mathrm{pH}$ in the highly productive surface waters increases as a result of surface production (Cai, 2003; Guo et al., 2012). However, a stratified water column can cause spatial decoupling of production and respiration, that is, surface-produced organic matter is respired in the lower water column at the expense of dissolved oxygen. This respiration gives rise to increased dissolved inorganic carbon and $\mathrm{pCO}_{2}$ levels and lower $\mathrm{pH}$ in the bottom waters. The bottom water $\mathrm{pH}$ decrease, as dissolved oxygen diminishes, may be aggravated further by interaction between open ocean source water acidification and coastal waters (Cai et al., 2011). Duarte et al. (2013) support the concept that

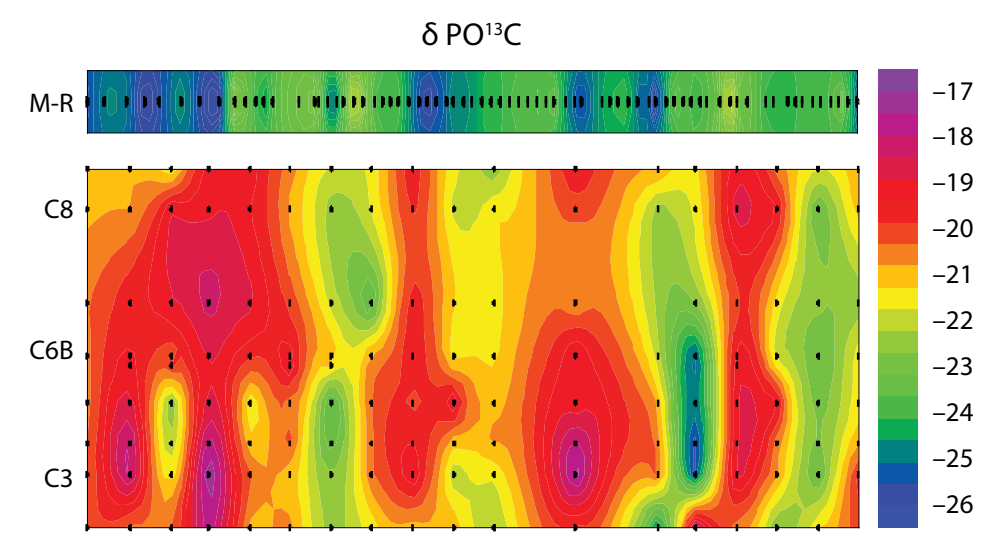

$\delta P \mathrm{P}^{15} \mathrm{~N}$
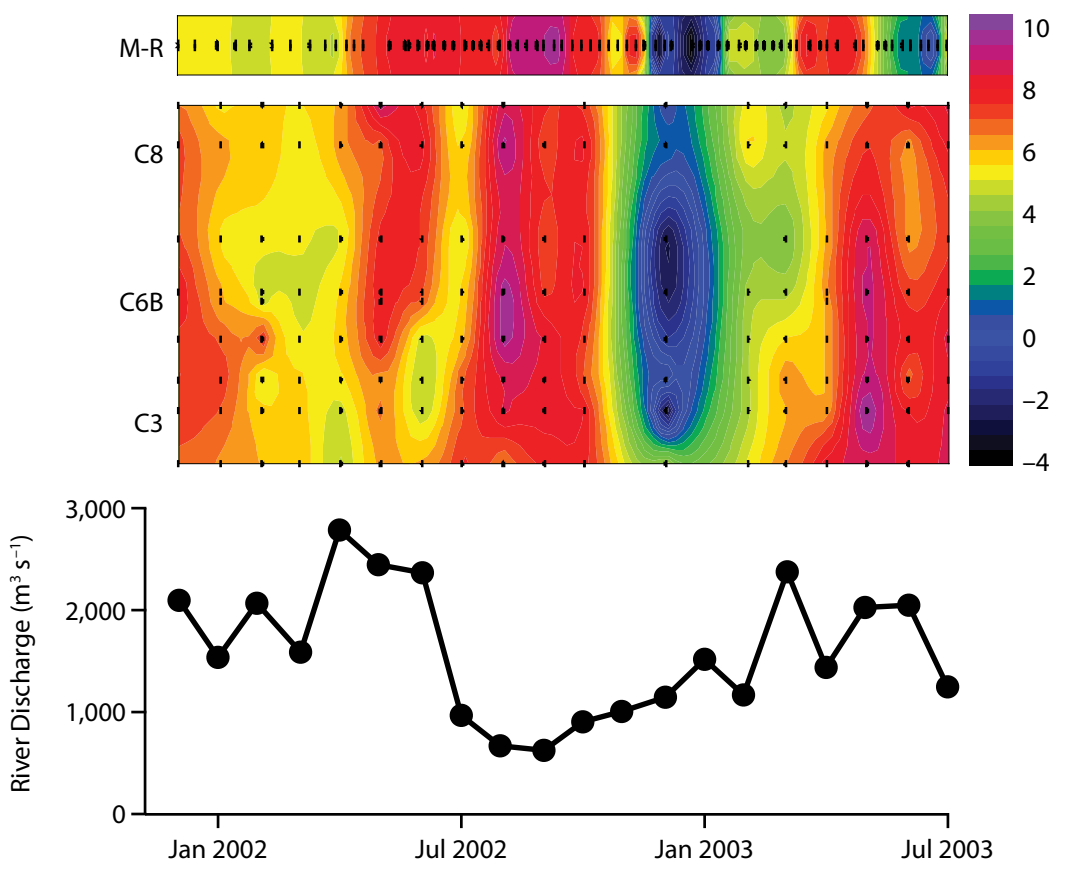

Figure 4. Sequence of particulate organic $\delta^{13} \mathrm{C}$ matter (upper panel) and particulate organic $\delta^{15} \mathrm{~N}$ matter (lower panel) in the Mississippi River (M-R, Baton Rouge, Louisiana) and transect C (station C8 offshore, station C6B mid-distance, and station C3 inshore, water depths of 30, 20, and $10 \mathrm{~m}$, respectively), $100 \mathrm{~km}$ west of the Mississippi River, from December 2001 to July 2003. Black marks represent sampling times and locations. Average monthly Mississippi River discharge $\left(\mathrm{m}^{3} \mathrm{~s}^{-1}\right)$ at Tarbert Landing is shown in the bottom panel. The terrestrial carbon signature $(-27$ to $-24 \%)$ in coastal surface waters parallels peaks in river discharge, and organic carbon offshore ( -22 to $-18 \%$ ) represents an atmospheric source. The $\mathrm{N}$ source of particulate organic matter along the $\mathrm{C}$ transect is primarily from the river $(-4$ to $10 \%)$ and subsequently incorporated into in situ production offshore. Courtesy of Björn Wissel, University of Regina, and Brian Fry, Griffith University. River data from US Geological Survey 
ocean acidification due to anthropogenic $\mathrm{CO}_{2}$ emissions cannot be transposed to coastal ecosystems directly and that a regional focus is necessary to predict future trajectories in the $\mathrm{pH}$ of coastal waters. Lowered $\mathrm{pH}$ in coastal waters, in conjunction with weakening seawater buffering capacity and seawater saturation state with respect to aragonite $\left(\Omega_{\text {arag }}\right)$ (Cai et al., 2011; Figure 5), remains a serious concern for living resources, especially with regard to shellfishery production. Increasing acidification could drive many coastal and estuarine waters into carbonate mineral undersaturation on a seasonal basis, affecting the stability of the carbonate skeletons of coastal mollusks (Cai et al., 2011; Duarte et al., 2013).

With continued accumulation of organic carbon at the seabed, microbial biomass and microbial decomposition potential of substrates and community oxygen consumption increase. The redox potential discontinuity layer in the sediments migrates upward to the sediment-water interface. Sulfate respiration replaces oxygen respiration, and hydrogen sulfide is generated from the sediments. Oxygen penetrates less deeply into the sediments as the bioturbation potential of the macroinfauna decreases during their demise due to sulfide toxicity or lack of sufficient oxygen. Evidence of sulfide is visible at the sediment-water interface in the forms of black spots resulting from iron sulfide that precipitates from intense microbial degradation of organic matter, lacey white colonies and denser, yellowish colonies of sulfur-oxidizing bacteria (Beggiatoa and Thiovulum), and reddish to violet carpets of sulfur-purple bacteria in the Wadden Sea (North Sea), in shallow water areas of the Baltic, on the Louisiana continental shelf, and in many areas of the world ocean where the oxygen minimum zone intersects
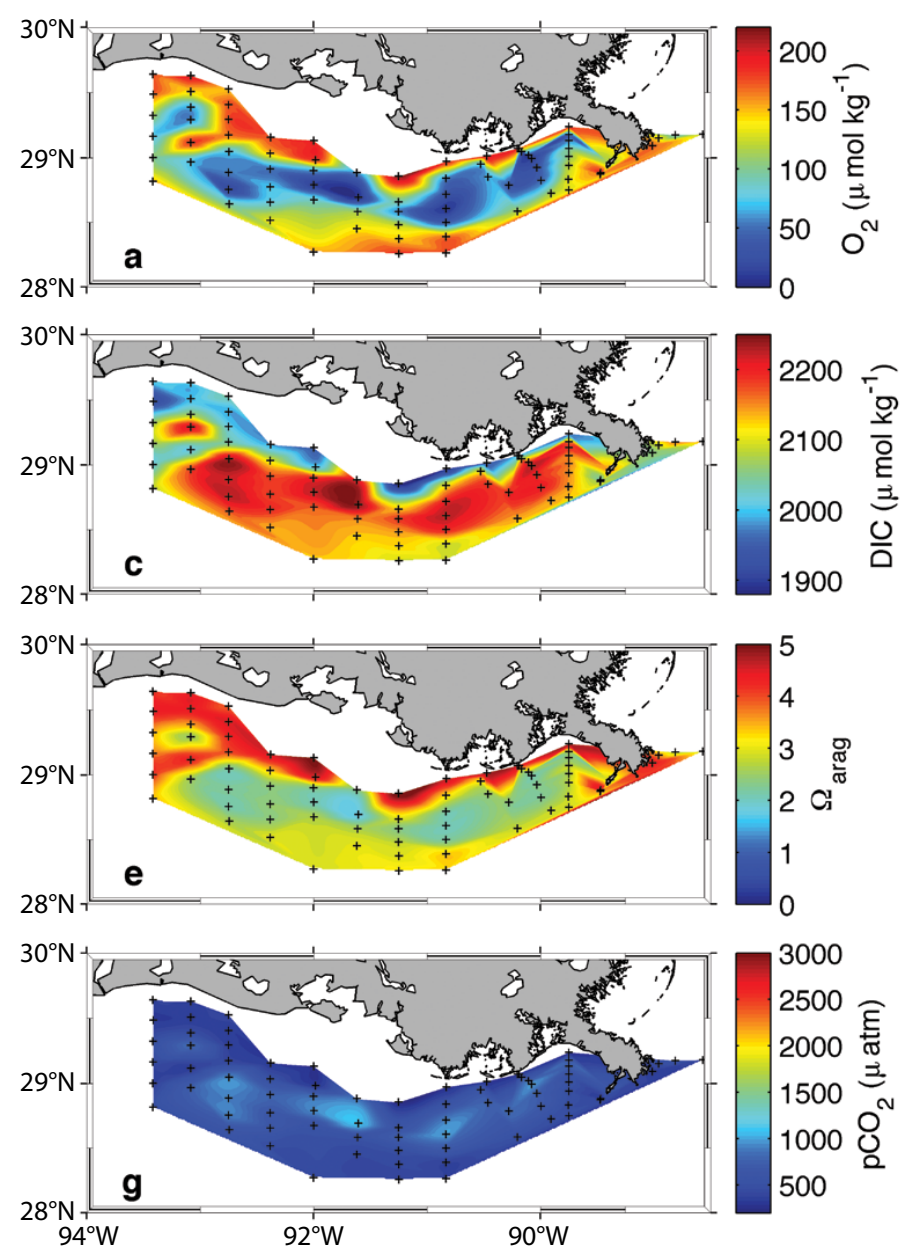
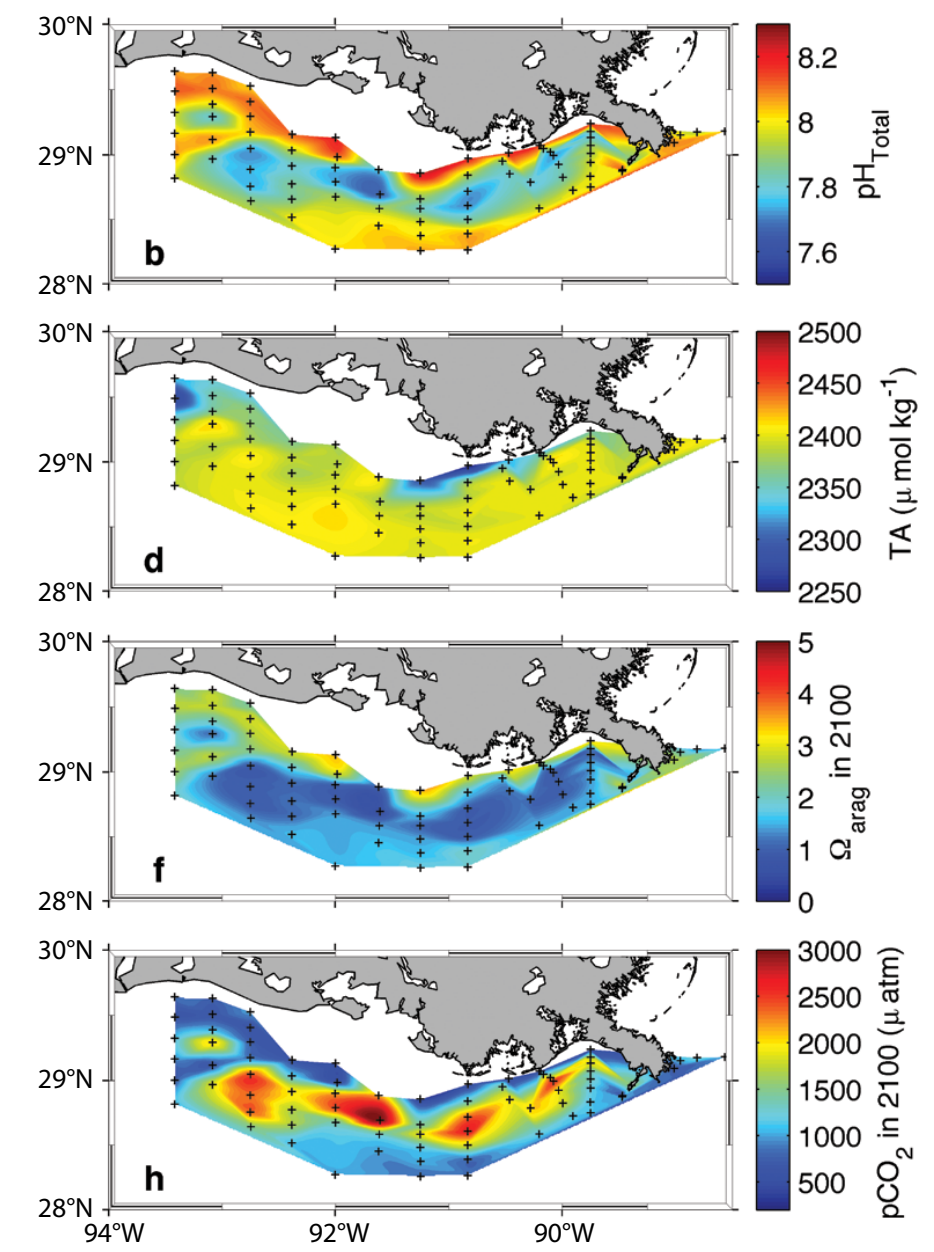

Figure 5. Spatial distributions of near-bottom water properties in the northern Gulf of Mexico in August 2007 and predicted conditions when atmospheric $\mathrm{CO}_{2}$ level reaches 800 ppm (as modeled in Cai et al., 2011). (a) Dissolved $\mathrm{O}_{2}$. (b) pH on total scale. (c) Dissolved inorganic carbon (DIC). (d) Total alkalinity (TA). (e,f) Seawater saturation state with respect to aragonite $\left(\Omega_{\text {arag }}\right)$. (g,h) $p \mathrm{CO}_{2}$. Panels a-f are modified from Cai et al. (2011) and used with permission from Nature Publishing Group $\odot$ 2011. Panels $g$ and $h$ are from authors W.-J. Cai and X. Hu 
the seabed (reviewed in Rabalais et al., 2001). When bottom water is depleted in oxygen, hydrogen sulfide may build up there as anaerobic bacteria metabolism reduces sulfate to $\mathrm{H}_{2} \mathrm{~S}$ (Jørgensen, 1980). The sediment becomes almost uniformly black, and there are no signs of aerobic life. While instrumentation may limit accurate detection of anoxia ( $\pm 0.2 \mathrm{mg} \mathrm{L}^{-1}$ precision, $6.2 \mu \mathrm{M}$ ), the presence of moderate $(20 \mu \mathrm{M}) \mathrm{H}_{2} \mathrm{~S}$ concentrations in bottom water indicate that the dissolved oxygen concentration is less than $0.2 \mathrm{mg} \mathrm{L}^{-1}(6.2 \mu \mathrm{M})$ and probably zero or close to it (Wong and Brewer, 1977). Hydrogen sulfide concentrations up to $50 \mu \mathrm{M}$ have been measured in bottom-water samples that emitted a strong odor of $\mathrm{H}_{2} \mathrm{~S}$ (Rabalais et al., 2007a). Hydrogen sulfide concentrations of 2 to $5 \mu \mathrm{M}$ have been chemically detected when there was still a faint $\mathrm{H}_{2} \mathrm{~S}$ odor. Sulfur-oxidizing bacteria at the sediment-water interface have been repeatedly observed by divers, through video surveillance from remotely operated vehicles (Rabalais et al., 2001), and in microscopically examined surface sediment samples.

Denitrification proceeds much of the year in normoxic waters, but it is dependent on the nitrate supplied by nitrification, a process that requires oxygen, which may be absent for extended periods and over broad areas of the seabed (Jäntti and Hietanen, 2012). Nitrogen removal at the oxic/anoxic interface can be a significant process. In the Baltic Sea, it accounts for as much nitrate removal as does sedimentary denitrification (Dalsgaard et al., 2013). Dissimilatory nitrate reduction to ammonium (DNRA), where nitrogen is not removed but instead recycled in the system, dominates nitrate reduction in low-oxygen conditions $\left(\mathrm{O}_{2}<110 \mu \mathrm{M}\right)$; this process has been persistent in the central Gulf of Finland during the past decade. The decrease of nitrogen removal rates is most likely caused by increased bottom water hypoxia (Jäntti and Hietanen, 2012). Moreover, nitrous oxide production increases under increasing sulfide concentrations (Dalsgaard et al., 2013). $\mathrm{N}$ can also be removed from the water column by anaerobic ammonium oxidation (anammox) processes, where nitrate and nitrite are reduced to dinitrogen gas under anoxic conditions. Anammox, despite its periodic occurrence in Baltic Sea sediments, is not regarded as a major nitrate-reduction pathway (Jäntti and Hietanen, 2012). With the shift in redox potential in the sediments as oxygen concentration decreases, fluxes of ammonium, silicate, and phosphate into the overlying water increase (Baustian, 2011). Under normoxic conditions, nitrate would be removed by denitrification.

Enhanced recycling of phosphate from surface sediments upon the onset of hypoxia and anoxia is a common phenomenon in coastal areas worldwide (e.g., Algeo and Ingall, 2007). The amount of dissolved inorganic phosphate released from sediments during the seasonal expansion of hypoxia in the Baltic Sea is approximately one order of magnitude greater than the total yearly anthropogenic phosphorus loading (Conley et al., 2002). This phosphate is released from reduction of $\mathrm{Fe}$-oxyhydroxides (Conley et al., 2009). Preferential regeneration of phosphate relative to carbon and nitrogen from organic matter under low-oxygen conditions also contributes to a surplus of bioavailable phosphate in the Baltic Sea (Jilbert et al., 2011).

The inorganic nutrients fluxed from the sediments into the overlying water column become available to fuel further phytoplankton production in the overlying water with the appropriate mixing mechanisms. The degree to which these nutrients diffuse upward through the water column and across strong pycnoclines depends on hydrographic features. High waves or strong currents will likely break down the physical structure of the water column, re-aerate it, and resuspend sediments and adsorbed and dissolved nutrients, with a subsequent, at least temporary, stimulatory effect for primary production.

\section{CHEMICAL CLUES TO HISTORIC CHANGE}

Evidence from biological paleoindicators (reviewed by Gooday et al., 2009) illustrates how communities of indicator benthic organisms (e.g., foraminiferans and ostracods) shifted or decreased in abundance and diversity as a result of severe, long-lasting hypoxic events. The sediments harbor a suite of chemical changes that can be used as indicators of either biological changes or biogeochemical change in the water column. The increased preservation of organic matter under anoxic conditions typically leads to elevated organic carbon content (Hartnett et al., 1998), and sediments overlain by anoxic waters are often also enriched in trace metals (Tribovillard et al., 2006). Sediment molybdenum (Mo) is a particularly robust indicator of sediments that are overlain by anoxic and sulfidic bottom waters. Records of Mo (commonly normalized to aluminum) document the recent human-induced decline in bottom water oxygen in, for example, Chesapeake Bay (Adelson et al., 2001) and the Baltic Sea (Jilbert and Slomp, 2013). Laminated sediments with high organic carbon (Zillén et al., 2008) and $\mathrm{Mo} / \mathrm{Al}$ ratios (Jilbert and Slomp, 
2013) characterize the early Holocene ( 8,000-4,000 years ago) and Medieval (800-1300 CE) periods of low oxygen in the Baltic Sea. Accumulation of biogenic silica (the remains of diatom frustules) increased in sediments under the Mississippi River plume as nutrient-enhanced primary production in the surface waters increased (Turner and Rabalais, 1994). Accumulating sediments influenced by the Mississippi River and Atchafalaya River plumes exhibit increases in $\% \mathrm{~N}, \% \mathrm{C}$, and $\% \mathrm{~S}$ (Figure 6) starting in 1940, based on
${ }^{210} \mathrm{~Pb}$-dated cores. The accompanying changes in $\delta^{13} \mathrm{C}, \delta^{15} \mathrm{~N}$, and $\delta^{34} \mathrm{~S}$ indicate recent ecosystem eutrophication in the form of increased marine in situ carbon formation, incorporation of Mississippi River nitrogen into marine in situ production, and increasing marine algal input and sulfide storage, respectively. Increased plant pigments stored in sediments, which indicate cyanobacterial or diatom blooms, may be the result of eutrophication or enhanced preservation due to hypoxic bottom waters (Rabalais et al., 2007b).
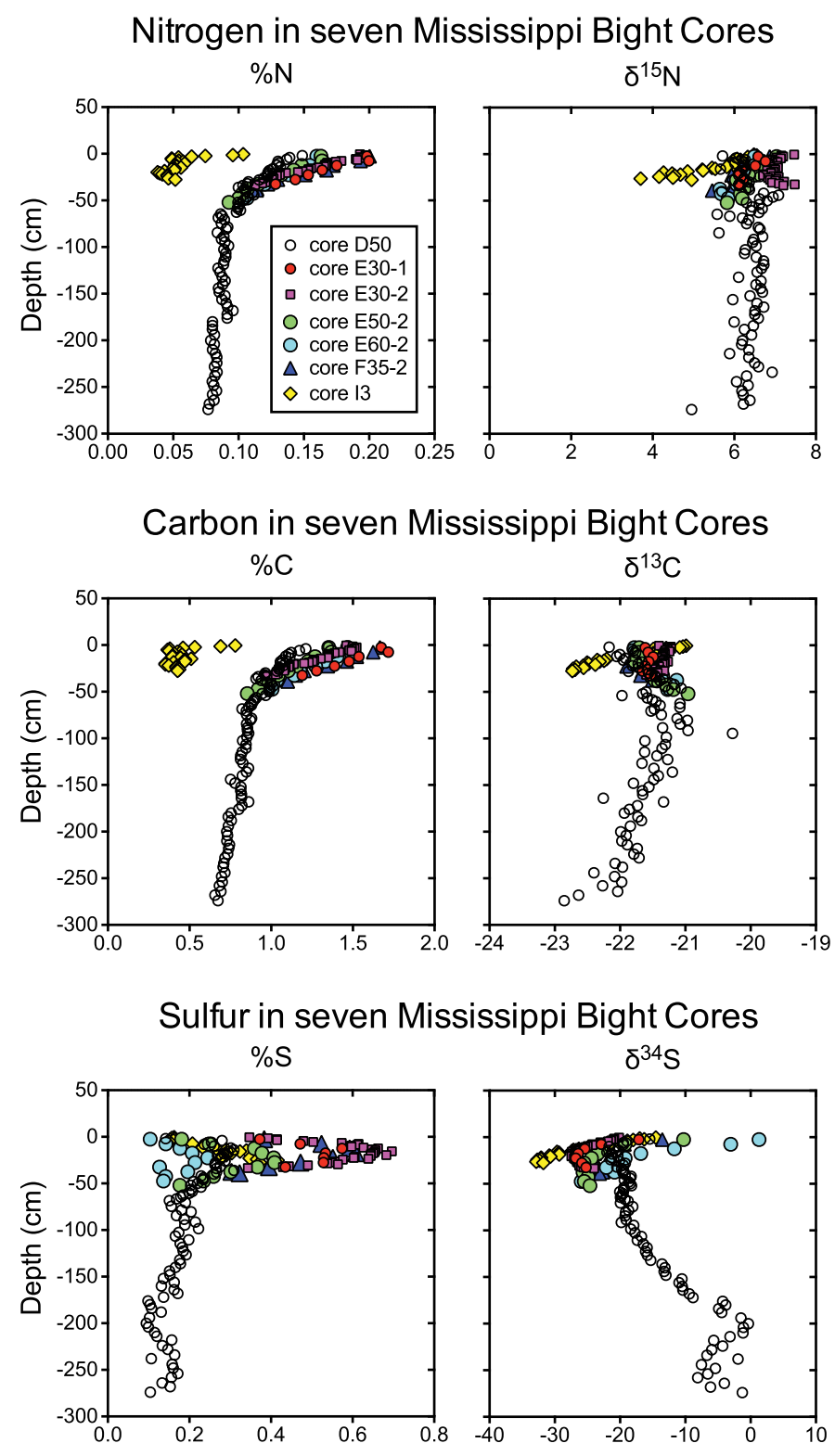

\section{CLIMATE CHANGE WILL}

LIKELY WORSEN LOW OXYGEN IN COASTAL WATERS

The world's climate has changed because of human activities, and it will continue to change even if greenhouse gas emissions are stabilized because of lagging impacts that will last for centuries.

The regional outcomes of the various global climate change (GCC) scenarios (IPCC, 2007, 2013) will be manifested in different and synergistic effects on components of ecosystems (Figure 7). The major drivers of these changes are increased temperature, altered hydrological cycles, and shifts in wind patterns that might alter coastal currents (Rabalais et al., 2010). The average global temperature is predicted to rise $0.4^{\circ} \mathrm{C}$ over the next three decades (IPCC, 2007), and 1.5 to $2^{\circ} \mathrm{C}$ in June-August over the coastal waters of the Gulf of Mexico by 2100 (IPCC, 2013). Increasing temperatures alone have the potential to strengthen density differences (pycnoclines) in estuarine and coastal waters, but lower surface salinity (e.g., from increased freshwater runoff) would be more of a factor in stratifying the water column. A stronger pycnocline should result in less diffusion of oxygen from the upper water column to the lower water column, leading to less dissolved oxygen in bottom waters.

Increased temperatures may also affect regional wind patterns, leading to changes in circulation and mixing. If wind patterns or intensity change, then coastal currents and their effects on coastal waters might also change, either aggravating a low-oxygen condition or, possibly, alleviating it. An example of the former can be found off the Oregon and Washington coasts, where winddriven shifts in the California current system in 2001 and subsequent years 
altered the long-term pattern of upwelling, resulting in extensive hypoxia along the inner shelf (Chan et al., 2008). If the frequency of tropical storms and hurricanes increases as a result of increased water temperatures in the lower to midlatitudes as predicted in GCC, there may be, at least, temporary water column mixing, destratification of the water column, and re-aeration of the bottom water (Rabalais et al., 2007a). However, such a disruption of a hypoxic zone would be temporary. A debate on the future severity and frequency of tropical storms continues.

The rates of biological processes, including both photosynthesis and respiration, are expected to increase with higher water temperatures up to a point. For instance, primary production may proceed at a faster rate but will eventually become limited by light (selfshading) or lack of nutrients. The former will result in greater primary production, and the latter, less.

Increased precipitation will result in more water, sediments, and nutrients reaching the coastal zone where they are likely to augment eutrophication through nutrient-enhanced production, increased stratification, or both (Rabalais et al., 2010). The upper part of the Mississippi River watershed falls within the area of North America predicted to experience increased runoff (higher precipitation) and earlier peak discharge (increased temperature) (IPCC, 2007, 2013; Milliman et al., 2008). Increased precipitation should result in increased erosion and loss of phosphorus and increased flux of dissolved inorganic nitrogen, particularly nitrate, through the soils and artificially drained agriculture areas. The combination of increased nutrient loads (from human activities) and increased freshwater discharge (from GCC) will aggravate the already high loads of nutrients from the Mississippi River to the northern Gulf of Mexico, strengthen stratification (all other factors remaining the same), and worsen the hypoxia situation (Rabalais et al., 2010). Reduced precipitation in other areas of the world, on the other hand, will lower the amount of nutrients and water reaching the coastal zone and, perhaps, lead to oligotrophication and reduced fisheries productivity (Nixon, 2004), or perhaps will alleviate hypoxia. The increase or decrease in flow (whichever occurs), flux of nutrients, and increased water temperature are likely to have important, but as yet not clearly identifiable, influences on hypoxia.

\section{CONCLUSION}

There is no doubt that the global increase in areas of hypoxia is real and not the result of expanded observations. Coastal water quality associated with hypoxia is currently on the decline and will surely decline further without a major reversal in nutrient loading or climate change. The likelihood of strengthened stratification alone, from increased surface water temperature as the global climate warms, is sufficient to worsen hypoxia where it currently exists and facilitate its formation in additional coastal waters. The interplay of increased nutrients and stratification may be offset temporarily by increased storminess, but tropical storm projections remain under debate. The consequences of

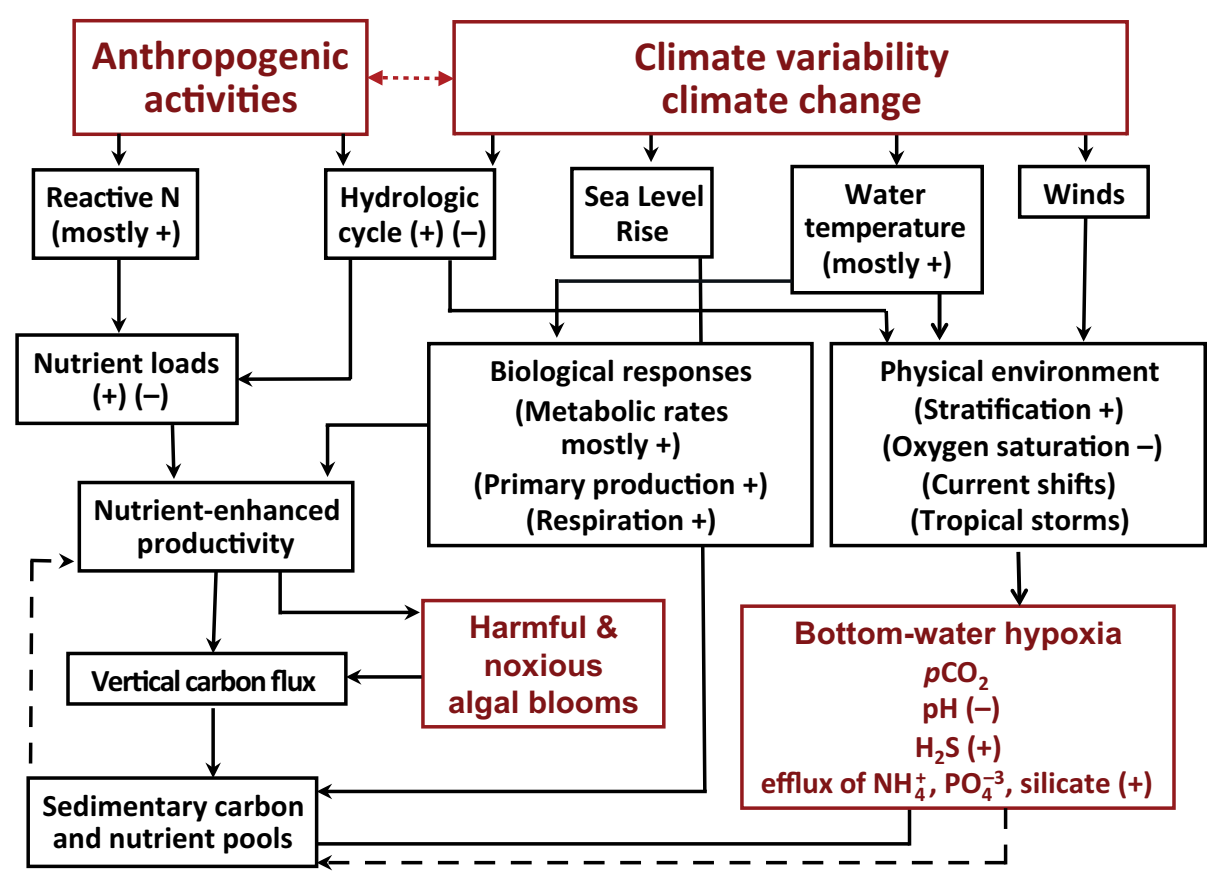

Figure 7. Conceptual diagram of the impacts of human and climate interactions on nutrientenhanced productivity, harmful and noxious algal blooms, and hypoxia formation (modified from Rabalais et al., 2010). Positive (+) interactions designate a worsening of conditions related to algal blooms and hypoxia, and negative (-) interactions designate fewer algal blooms and lessening of hypoxia symptoms. Dashed lines indicate negative feedback processes to nutrient-enhanced production and subsequent hypoxia. The dotted line between "Anthropogenic activities" and "Climate variability/climate change" indicates that humans largely drive current climate change, but that climate change can certainly affect human activities. Modified from Rabalais et al. (2010), used under Copyright Agreement with Copernicus Press. 
eutrophication-induced hypoxia can be reversed if long-term, broad-scale, and persistent efforts to reduce substantial nutrient loads are developed and implemented. The need for water and resource managers to reduce nutrient loads even, if at a minimum, to maintain the current status, is critical in view of the significant effects of globally expanding hypoxia.

\section{ACKNOWLEDGEMENTS}

Funding for this synthesis was provided by the National Oceanographic and Atmospheric Administration, Center for Sponsored Coastal Ocean Research program, NGOMEX09; the BP-funded Gulf of Mexico Research Initiative to Coastal Waters Consortium and RFP-II award GoMRI-020; and the National Science Foundation, Coupled Human Natural Systems, award 1009417, OCE-0752110, and OCE 0752254.

\section{REFERENCES}

Adelson, J.M., G.R. Helz, and C.V. Miller. 2001. Reconstructing the rise of recent coastal anoxia: Molybdenum in Chesapeake Bay sediments. Geochimica et Cosmochimica Acta 65:237-252, http://dx.doi.org/10.1016/ S0016-7037(00)00539-1.

Algeo, T.J., and E. Ingall. 2007. Sedimentary $\mathrm{C}_{\text {org }}: \mathrm{P}$ ratios, paleocean ventilation, and Phanerozoic atmospheric $\mathrm{pO}_{2}$. Palaeogeography, Palaeoclimatology, Palaeoecology 256:130-155, http://dx.doi.org/10.1016/j.palaeo.2007.02.029.

Baden, S.P., L.-O. Loo, L. Pihl, and R. Rosenberg. 1990. Effects of eutrophication on benthic communities including fish: Swedish west coast. Ambio 19:113-122, http://www.jstor.org/ stable/4313676.

Baustian, M.M. 2011. Microphytobenthos of the northern Gulf of Mexico hypoxic area and their role in oxygen dynamics. PhD Dissertation, Louisiana State University, Baton Rouge.

Bennett, E.M., S.R. Carpenter, and N.F. Caraco. 2001. Human impact on erodable phosphorus and eutrophication: A global perspective. BioScience 51:227-234, http://dx.doi.org/ 10.1641/0006-3568(2001)051[0227:HIOEPA] 2.0.CO;2.

Brush, G.S. 2009. Historical land use, nitrogen, and coastal eutrophication: A paleoecological perspective. Estuaries and Coasts 32:18-28, http://dx.doi.org/10.1007/s12237-008-9106-z.
Cai, W.-J. 2003. Riverine inorganic carbon flux and rate of biological uptake in the Mississippi River plume. Geophysical Research Letters 30, 1032, http://dx.doi.org/10.1029/2002GL016312.

Cai, W.-J., X. Hu, W.-J. Huang, M.C. Murrell, J.C. Lehrter, S.E. Lohrenz, W.-C. Chou, W. Zhai, J.T. Hollibaugh, Y. Wang, and others. 2011. Acidification of subsurface coastal waters enhanced by eutrophication. Nature Geoscience 4:766-770, http://dx.doi.org/ 10.1038/ngeo1297.

Chan, F., J. Barth, J. Lubchenco, J. Kirincich, A. Weeks, H. Peterson, W.T. Menge, and B.A. Chan. 2008. Emergence of anoxia in the California Current Large Marine Ecosystem. Science 319:920, http://dx.doi.org/10.1126/ science.1149016.

Chen, C.-C., G.-C. Gong, and F.-K. Shiah. 2007. Hypoxia in the East China Sea: One of the largest coastal low-oxygen areas in the world. Marine Environmental Research 64:399-408, http://dx.doi.org/ 10.1016/j.marenvres.2007.01.007.

Conley, D., S. Björk, E. Bonsdorff, J. Carstensen, G. Destouni, B.G. Gustafsson, S. Hietanen, M. Kortekaas, H. Kuosa, and others. 2009. Hypoxia-related processes in the Baltic Sea. Environmental Science and Technology 43:3,412-3,420, http://dx.doi.org/ 10.1021/es802762a.

Conley, D.J., J. Carstensen, J. Aigars, P. Axe, E. Bonsdorff, T. Eremina, B.-M. Haahti, C. Humborg, P. Jonsson, J. Kotta, and others. 2011. Hypoxia is increasing in the coastal zone of the Baltic Sea. Environmental Science and Technology 45:6,777-6,783, http://dx.doi.org/10.1021/es201212r.

Conley, D.J., C. Humborg, L. Rahm, O.P. Savchuk, and F. Wulff. 2002. Hypoxia in the Baltic Sea and basin-scale changes in phosphorus biogeochemistry. Environmental Science and Technology 36:5,315-5,320, http://dx.doi.org/ 10.1021/es025763w.

Cooper, S.R., and G.S. Brush. 1991. Longterm history of Chesapeake Bay anoxia. Science 254:992-996, http://dx.doi.org/10.1126/ science.254.5034.992.

Dalsgaard, T., L.D. Brabandere, and P.O.J. Hall. 2013. Denitrification in the water column of the central Baltic Sea. Geochimica et Cosmochimica Acta 106:247-260, http://dx.doi.org/10.1016/ j.gca.2012.12.038.

Díaz, R.J., and R. Rosenberg. 2008. Spreading dead zones and consequences for marine ecosystems. Science 321:926-929, http://dx.doi.org/10.1126/ science. 1156401.

Duarte, C.M., I.E. Hendriks, T.S. Moore, Y.S. Olsen, A. Steckbauer, L. Ramajo, J. Carstensen, J.A. Trotter, and M. McCulloch. 2013. Is ocean acidification an open-ocean syndrome? Understanding anthropogenic impacts on seawater pH. Estuaries and Coasts 36:221-236, http://dx.doi.org/10.1007/s12237-013-9594-3.

Fonselius, S.H. 1969. Hydrography of the Baltic deep basins III. Pp. 1-97 in Series Hydrography Report No. 23, Fishery Board of Sweden, Gothenberg.
Galloway, J.N., A.R. Townsend, J.W. Erisman, M. Bekunda, Z. Cai, J.R. Freney, L. Martinelli, S.P. Seitzinger, and M.A. Sutton. 2008. Transformation of the nitrogen cycle: Recent trends, questions, and potential solutions. Science 320:889-892, http://dx.doi.org/10.1126/ science. 1136674 .

Gilbert, D., N.N. Rabalais, R.J. Díaz, and J. Zhang. 2010. Evidence for greater oxygen depletion rate declines in the coastal ocean than in the open ocean. Biogeosciences 7:2,283-2,296, http://dx.doi.org/10.5194/bg-7-2283-2010.

Gooday, A.J., F. Jorissen, L.A. Levin, J.J. Middelburg, S.W.A. Naqvi, N.N. Rabalais, M. Scranton, and J. Zhang. 2009. Historical records of coastal eutrophicationinduced hypoxia. Biogeosciences 6:1-39, http://dx.doi.org/10.5194/bg-6-1707-2009.

Guo, X., W.-J. Cai, W.-J. Huang, Y. Wang, F. Chen, M.C. Murrell, S.E. Lohrenz, L.-Q. Jiang, M. Dai, J. Hartmann, and others. 2012. Carbon dynamics and community production in the Mississippi River plume. Limnology and Oceanography 57:1-17, http://dx.doi.org/ 10.4319/lo.2012.57.1.0001.

Hagy, J.D., W.R. Boynton, C.W. Keefe, and K.V. Wood. 2004. Hypoxia in Chesapeake Bay, 1950-2001: Long-term change in relation to nutrient loading and river flow. Estuaries 27:634-658, http://dx.doi.org/10.1007/ BF02907650.

Hartnett, H., R.G. Keil, J.J. Hedges, and A.H. Devol. 1998. Influence of oxygen exposure time on organic carbon preservation in continental margin sediments. Nature 391:572-574, http:// dx.doi.org/10.1038/35351.

Helly, J.J., and L.A. Levin. 2004. Global distribution of naturally occurring marine hypoxia on continental margins. Deep Sea Research Part I 51:1,159-1,168 http://dx.doi.org/ 10.1016/j.dsr.2004.03.009.

Hofmann, A.F., E.T. Peltzer, P.M. Walz, and P.G. Brewer. 2011. Hypoxia by degrees: Establishing definitions for a changing ocean. Deep-Sea Research Part I 58:1,212-1,226, http://dx.doi.org/10.1016/j.dsr.2011.09.004.

Intergovernmental Panel on Climate Change (IPCC). 2007. Climate Change 2007: Impacts, Adaptation and Vulnerability. Contribution of Working Group II to the Fourth Assessment Report of the Intergovernmental Panel on Climate Change. M.I. Parry. O.F. Canziani, J.P. Patulikof, P.J. van der Linden, and C.E. Hanson, eds, Cambridge University Press, Cambridge, UK.

IPCC. 2013. Climate Change 2013: The Physical Science Basis. Group I Contribution to the IPCC Fifth Assessment Report, Intergovernmental Panel on Climate Change, Stockholm. Available online at: http://www.ipcc.ch/report/ar5/wg1 (accessed November 18, 2013).

Jäntti, H., and S. Hietanen. 2012. The effects of hypoxia on sediment nitrogen cycling in the Baltic Sea. Ambio 41:161-169, http:// dx.doi.org/10.1007/s13280-011-0233-6. 
Jilbert, T., and C.P. Slomp. 2013. Rapid highamplitude variability in Baltic Sea hypoxia during the Holocene. Geology 41:1,183-1,186, http://dx.doi.org/10.1130/G34804.1.

Jilbert, T., C.P. Slomp, B.G. Gustafsson, and W. Boer. 2011. Beyond the Fe-P redox connection: Preferential regeneration of phosphorus from organic matter as a key control on Baltic Sea nutrient cycles. Biogeosciences 8:1,699-1,720, http://dx.doi.org/ 10.5194/bg-8-1699-2011.

Jørgensen, B.B. 1980. Seasonal oxygen depletion in the bottom waters of a Danish fiord and its effect on the benthic community. Oikos 34:68-76.

Justić, D., T. Legović, and L. Rottini-Sandrini. 1987. Trends in oxygen content 1911-1984 and occurrence of benthic mortality in the northern Adriatic Sea. Estuarine, Coastal and Shelf Science 25:435-445, http://dx.doi.org/ 10.1016/0272-7714(87)90035-7.

Justić, D., N.N. Rabalais, and R.E. Turner. 1995. Stoichiometric nutrient balance and origin of coastal eutrophication. Marine Pollution Bulletin 30:41-66, http://dx.doi.org/ 10.1016/0025-326X(94)00105-I.

Karlson, K., R. Rosenberg, and E. Bonsdorff. 2002 Temporal and spatial large-scale effects of eutrophication and oxygen deficiency on benthic fauna in Scandinavian and Baltic waters: A review. Oceanography and Marine Biology Annual Review 40:427-489, http://dx.doi.org/ 10.1201/9780203180594.ch8.

Keeling, R.F., A. Körtzinger, and N. Gruber. 2010. Ocean deoxygenation in a warming world. Annual Review of Marine Science 2:463-493, http://dx.doi.org/10.1146/annurev.marine. 010908.163855.

Levin, L.A. 2003. Oxygen minimum zone benthos: Adaptation and community response to hypoxia. Pp. 1-45 in Oceanography and Marine Biology, An Annual Review, vol. 41. R.N. Gibson and J.A. Atkinson, eds, CRC Press.

Liu, K.-K., L. Atkinson, R. Quiñones, and L. Talaue-McManus. 2010. Carbon and Nutrient Fluxes in Continental Margins: A Global Synthesis. IGBP Book Series, Springer, Berlin, $741 \mathrm{pp}$.

Middelburg, J., and L.A. Levin. 2009. Coastal hypoxia and sediment biogeochemistry. Biogeosciences 6:1,273-1,293, http://dx.doi.org/ 10.5194/bg-6-1273-2009.

Milliman, J.D., K.L. Farnsworth, P.D. Jones, K.H. Xu, and L.C. Smith. 2008. Climatic and anthropogenic factors affecting river discharge to the global ocean, 1951-2000. Global and Planetary Change 62:187-194, http://dx.doi.org/ 10.1016/j.gloplacha.2008.03.001.

Nixon, S.W. 2004. The artificial Nile. American Scientist 94:158-165, http://dx.doi.org/10.1511/ 2004.2.158.

Parsons, M.L., Q. Dortch, and R.E. Turner. 2002. Sedimentological evidence of an increase in Pseudo-nitzschia (Bacillariophyceae) abundance in response to coastal eutrophication. Limnology and Oceanography 47(2):551-558, http://dx.doi.org/10.4319/lo.2002.47.2.0551.
Pomeroy, L.R., J.E. Sheldon, W.M. Sheldon, J.O. Blanton, J. Amft, and F. Peters. 2000. Seasonal changes in microbial processes in estuarine and continental shelf waters of the south-eastern USA. Estuarine Coastal and Shelf Science 51:415-428, http://dx.doi.org/10.1006/ ecss.2000.0690.

Quiñones-Rivera, Z.J., B. Wissel, D. Justić, and B. Fry 2007. Partitioning oxygen sources and sinks in a stratified, eutrophic coastal ecosystem using stable oxygen isotopes. Marine Ecology Progress Series 342:60-83, http://dx.doi.org/10.3354/meps342069.

Quiñones-Rivera, Z.J., B. Wissel, N.N. Rabalais, and D. Justić. 2010. Effects of biological and physical factors on seasonal oxygen dynamics in a stratified, eutrophic coastal ecosystem. Limnology and Oceanography 55:289-304, http://dx.doi.org/10.4319/lo.2010.55.1.0289.

Rabalais, N.N. 2004. Eutrophication. Pp. 819-865 in The Global Coastal Ocean: Multiscale Interdisciplinary Processes. The Sea: Ideas and Observations on Progress in the Study of the Seas, vol. 13. A.R. Robinson, J. McCarthy, and B.J. Rothschild, eds, Harvard University Press, Cambridge, Massachusetts.

Rabalais, N.N., R.J. Díaz, L.A. Levin, R.E. Turner, D. Gilbert, and J. Zhang. 2010. Dynamics and distribution of natural and human-caused coastal hypoxia. Biogeosciences 7:585-619, http://dx.doi.org/10.5194/bg-7-585-2010.

Rabalais, N.N., D.E. Harper Jr., and R.E. Turner. 2001. Responses of nekton and demersal and benthic fauna to decreasing oxygen concentrations. Pp. 115-128 in Coastal Hypoxia: Consequences for Living Resources and Ecosystems Coastal and Estuarine Studies, vol. 58. N.N. Rabalais and R.E. Turner, eds, American Geophysical Union, Washington, DC.

Rabalais, N.N., R.E. Turner, and D. Scavia. 2002. Beyond science into policy: Gulf of Mexico hypoxia and the Mississippi River. BioScience 52:129-142, http:// dx.doi.org/10.1641/0006-3568(2002)052 [0129:BSIPGO]2.0.CO;2.

Rabalais, N.N., R.E. Turner, B.K. Sen Gupta, D.F. Boesch, P. Chapman, and M.C. Murrell. 2007a. Hypoxia in the northern Gulf of Mexico: Does the science support the Plan to Reduce, Mitigate, and Control Hypoxia? Estuaries and Coasts 30:753-772, http://dx.doi.org/10.1007/ BF02841332.

Rabalais, N.N., R.E. Turner, B.K. Sen Gupta, E. Platon, and M.L. Parsons. 2007b. Sediments tell the history of eutrophication and hypoxia in the northern Gulf of Mexico. Ecological Applications 17:S129-S143, http://dx.doi.org/ 10.1890/06-0644.1.

Tribovillard, N., T.J. Algeo, T. Lyons, and A. Riboulleau. 2006. Trace metals as paleoredox and paleoproductivity proxies: An update. Chemical Geology 232(1-2):12-32, http:// dx.doi.org/10.1016/j.chemgeo.2006.02.012.

Turner, R.E., N. Qureshi, N.N. Rabalais, Q. Dortch, D. Justić, R.F. Shaw, and J. Cope. 1998. Fluctuating silicate:nitrate ratios and coastal plankton food webs. Proceedings of the National Academy Sciences of the United States of America 95:13,048-13,051, http://dx.doi.org/ 10.1073/pnas.95.22.13048.

Turner, R.E., and N.N. Rabalais. 1994. Coastal eutrophication near the Mississippi River delta. Nature 368:619-621, http://dx.doi.org/ $10.1038 / 368619 \mathrm{a} 0$.

Turner, R.E., and N.N. Rabalais. 2013. Nitrogen and phosphorus phytoplankton growth limitation in the northern Gulf of Mexico. Aquatic Microbial Ecology 68:159-169, http://dx.doi.org/ 10.3354/ame01607.

Turner, R.E., N.N. Rabalais, R.B. Alexander, G. McIsaac, and R.W. Howarth. 2007. Characterization of nutrient, organic carbon and sediment loads from the Mississippi River into the northern Gulf of Mexico. Estuaries and Coasts 30(5):773-790.

Turner, R.E., N.N. Rabalais, and D. Justić. 2012. Predicting summer hypoxia in the northern Gulf of Mexico: Redux. Marine Pollution Bulletin 64:319-324, http://dx.doi.org/10.1016/ j.marpolbul.2011.11.008.

Vaquer-Sunyer, R., and C.M. Duarte. 2008. Thresholds of hypoxia for marine biodiversity. Proceedings of The National Academy of Sciences of the United States of America 105(40):15,452-15,457, http:// dx.doi.org/10.1073/pnas.0803833105.

Voss, M., H.W. Bange, J.W. Dippner, J.J. Middelburg, J.P. Montoya, and B. Ward. 2013. The marine nitrogen cycle: Recent discoveries, uncertainties and the potential relevance of climate change. Philosophical Transactions of the Royal Society B 368, http://dx.doi.org/ 10.1098/rstb.2013.0121.

Wang, X.-C., R.F. Chen, and G.B. Gardner. 2004. Sources and transport of dissolved and particulate organic carbon in the Mississippi River estuary and adjacent coastal waters of the northern Gulf of Mexico. Marine Chemistry 89:241-256, http://dx.doi.org/ 10.1016/j.marchem.2004.02.014.

Wong, G.T.F., and P.G. Brewer. 1977. The marine chemistry of iodine in anoxic basins. Geochimica et Cosmochimica Acta 41:151-159, http://dx.doi.org/ 10.1016/0016-7037(77)90195-8.

Zaitsev, Y.P. 1992. Recent changes in the trophic structure of the Black Sea. Fisheries Oceanography 1:180-189, http://dx.doi.org/ 10.1111/j.1365-2419.1992.tb00036.x.

Zillén, L., D.J. Conley, T. Andrén, E. Andrén, and S. Björck. 2008. Past occurrences of hypoxia in the Baltic Sea and the role of climate variability, environmental change and human impact. Earth-Science Reviews 91:77-92, http:// dx.doi.org/10.1016/j.earscirev.2008.10.001. 